\title{
Ferrous Iron Release from Transferrin by Human Neutrophil-Derived Superoxide Anion: Effect of $\mathrm{pH}$ and Iron Saturation
}

\author{
Joan K. Brieland ${ }^{*, 1}$ and Joseph C. Fantone \\ *Unit for Laboratory Animal Medicine and the Department of Pathology, University of Michigan \\ Medical School, Ann Arbor, Michigan 48109
}

Received June 15, 1990, and in revised form August 29, 1990

The ability of superoxide anion $\left(\mathrm{O}_{2}^{-}\right)$from stimulated human neutrophils (PMNs) to release ferrous iron $\left(\mathrm{Fe}^{2+}\right.$ ) from transferrin was assessed. At pH 7.4, unstimulated PMNs released minimal amounts of $\mathrm{O}_{2}^{-}$and failed to facilitate the release of $\mathrm{Fe}^{2+}$ from holosaturated transferrin. In contrast, incubation of phorbol myristate acetate (PMA)-stimulated PMNs with holosaturated transferrin at $\mathrm{pH} 7.4$ enhanced the release of $\mathrm{Fe}^{2+}$ from transferrin eightfold in association with marked generation of $\mathrm{O}_{2}^{-}$. The release of $\mathrm{Fe}^{2+}$ was inhibited by addition of superoxide dismutase (SOD), indicating that the release of $\mathrm{Fe}^{2+}$ was dependent on PMN-derived extracellular $\mathrm{O}_{2}^{-}$. In contrast, at physiologic pH (7.4), incubation of transferrin at physiological levels of iron saturation (e.g. 32\%) with unstimulated or PMA stimulated PMNs failed to facilitate the release of $\mathrm{Fe}^{2+}$. The effect of decreasing the pH on the release of $\mathrm{Fe}^{2+}$ from transferrin by PMN-derived $\mathrm{O}_{2}^{-}$was determined. Decreasing the $\mathrm{pH}$ greatly facilitated the release of $\mathrm{Fe}^{2+}$ from both holosaturated transferrin and from transferrin at physiological levels of iron saturation by $\mathrm{PMN}$-derived $\mathrm{O}_{2}^{-}$. Release of $\mathrm{Fe}^{2+}$ occurred despite a decrease in the amount of extracellular $\mathrm{O}_{2}^{-}$generated by $\mathrm{PMNs}$ in an acidic environment. These results suggest that transferrin at physiologic levels of iron saturation may serve as a source of $\mathrm{Fe}^{2+}$ for biological reactions in disease states where activated phagocytes are present and there is a decrease in tissue pH. The unbound iron could participate in biological reactions including promoting propagation of lipid peroxidation reactions or hydroxyl radical formation following reaction with phagocytic cell-derived hydrogen peroxide. (c) 1991 Academic Press, Inc.

In recent years there has been increasing evidence that iron plays an important role in promoting tissue injury

${ }^{1}$ To whom correspondence should be addressed. at sites of inflammation (1). This may occur secondary to the promotion of lipid peroxidation reactions or ironcatalyzed hydroxyl radical $\left({ }^{\circ} \mathrm{OH}\right)$ formation via a Fenton reaction. However, under normal physiologic conditions, free iron does not exist in plasma or extracellular fluids and is not readily available for participation in biological reactions. Iron $\left(\mathrm{Fe}^{3+}\right)$ is carried in the vertebrate bloodstream bound to transferrin in a ternary complex involving iron, transferrin, and bicarbonate (2-6) and is unable to promote oxidant-induced tissue injury in this bound state.

A most challenging problem in transferrin chemistry is the identification of mechanisms by which transferrin is induced to release iron (7). Reduction of $\mathrm{Fe}^{3+}$ to ferrous iron $\left(\mathrm{Fe}^{2+}\right)$, which binds weakly to transferrin, is one mechanism for the release of free iron from transferrin $(3,4,8)$. The susceptibility of transferrin-bound $\mathrm{Fe}^{3+}$ to reduction can be enhanced by multiple factors. Under conditions of increasing hydrogen ion concentration, the $\mathrm{Fe}^{3+} \cdot$ transferrin $\cdot$ bicarbonate complex experiences a conformational change, resulting in a decrease in binding affinity of transferrin for iron $(2,9-11)$. Theoretically, $\mathrm{Fe}^{3+}$, which is buried in the protein at physiologic $\mathrm{pH}$ (7.4), becomes more accessible to reduction, following conformational changes resulting from interaction of transferrin with hydrogen ion (12-14).

Phagocytic cells, including human polymorphonuclear leukocytes (PMNs), ${ }^{2}$ can release reactive oxygen metabolites including superoxide anion $\left(\mathrm{O}_{2}^{-}\right)$following activation (15). Although there have been extensive in vitro studies examining the ability of reducing agents like sodium di-

${ }^{2}$ Abbreviations used: PMN, polymorphonuclear leukocytes; HBSS, Hanks' balanced salt solution; PBS, phosphate-buffered saline; SOD, superoxide dismutase; BPS, bathophenanthroline disulfonate; NTA, nitrilotriacetic acid; BSA, bovine serum albumin; TRF, transferrin; APOTRF, apotransferrin. 
thionite (3), thioglycolate (3), and ascorbate (6) to facilitate the release of $\mathrm{Fe}^{2+}$ from transferrin, the ability of $\mathrm{PMN}$-derived $\mathrm{O}_{2}^{-}$to facilitate the release of $\mathrm{Fe}^{2+}$ from $\mathrm{Fe}^{3+} \cdot$ transferrin $\cdot \mathrm{HCO}_{3}^{2-}$ has not been thoroughly investigated (16). In the following in vilro experiments we assessed the effect of iron saturation and decreasing $\mathrm{pH}$ on the ability of PMN-derived $\mathrm{O}_{2}^{-}$to facilitate the release of $\mathrm{Fe}^{2+}$ from transferrin.

\section{MATERIALS AND METHODS}

Chemicals. All chemicals were purchased from Sigma Chemical Co. (St. Louis, MO) unless otherwise noted.

Isolation of PMNs. Human PMNs were isolated from citrated blood as described previously $(17,18)$. Briefly, PMNs were obtained from whole blood by Ficoll Hypaque (Pharmacia, Piscataway, NJ) density gradient centrifugation, dextran sedimentation, and hypotonic lysis of red cells Purified PMNs were resuspended at $10^{6}$ cells $/ \mathrm{ml}$ in Hanks' balanced salt solution (HBSS). In selected experiments, cells were suspended in phosphate-buffered saline (PBS) containing $1 \mathrm{mM}$ calcium, $0.5 \mathrm{mM}$ magnesium, and $0.1 \%$ dextrose.

Superoxide anion generation. Extracellular superoxide anion generation by PMNs was measured spectrophotometrically by the superoxide dismutase (SOD) inhibitable reduction of ferricytochrome $c$ (19). PMNs $\left(3 \times 10^{6}\right)$ were suspended in $3 \mathrm{ml} \mathrm{HBSS}$ containing $160 \mu \mathrm{M}$ ferricytochrome $c$ and stimulated with phorbol myristate acetate [PMA $(100 \mathrm{ng} / \mathrm{ml}$ final $)]$. The rate of extracellular $\mathrm{O}_{2}^{-}$generated $/ \mathrm{min}$ was determined by the change in absorbance/min at $550 \mathrm{~nm}$ of PMN cell supernatants \pm SOD $(90 \mathrm{U} / \mathrm{ml}$ final). The difference in absorbance per sample \pm SOD divided by the extinction coefficient $\left(21.1 \times 10^{3} \mathrm{M}^{-1}\right.$ $\mathrm{cm}^{-1}$ ) yielded nanomoles $\mathrm{O}_{2}^{-} / 10^{6} \mathrm{PMNs} / \mathrm{min}$. All spectrophotometric measurements were conducted with a dual beam Cary 210 spectrophotometer (Varian Instruments, Palo Alto, CA). The lower limit of AU change that can be measured accurately under conditions in these experiments is 0.001 .

Release of $\mathrm{Fe}^{2+}$ from holosaturated transferrin. The release of $\mathrm{Fe}^{2+}$ from holosaturated transferrin by $\mathrm{PMN}$-derived $\mathrm{O}_{2}^{-}$was monitored spectrophotometrically $(535 \mathrm{~nm})$ as described previously (3). Briefly, unstimulated and stimulated [PMA $(100 \mathrm{ng} / \mathrm{ml}$ final $)]$ PMNs $\left(10^{6}\right)$ were incubated in $1 \mathrm{ml}$ HBSS containing iron-saturated transferrin $(0.060$ $\mathrm{mM}$ final), bathophenanthroline disulfonate (BPS) $(0.50 \mathrm{mM}$ final) with and without SOD $\left(90 \mathrm{U} / \mathrm{ml}\right.$ final) for $20 \mathrm{~min}$ in a $37^{\circ} \mathrm{C}$ shaking water bath. Catalase $(100 \mathrm{U} / \mathrm{ml})$ was included in the reaction to inhibit the potential oxidation of $\mathrm{Fe}^{2+}$ by hydrogen peroxide. The samples were centrifuged $\left(300 \mathrm{~g}, 10 \mathrm{~min}, 20^{\circ} \mathrm{C}\right)$ and the cell supernatants removed. The $\mathrm{O}_{2}^{-}$-dependent release of $\mathrm{Fe}^{2+}$ was determined by the difference in absorbance at $535 \mathrm{~nm}$ of samples with and without SOD. The difference in absorbance was divided by the extinction coefficient $\left(2.214 \times 10^{4} \mathrm{M}^{-1}\right.$ $\mathrm{cm}^{-1}$ ) yielding nanomoles $\mathrm{Fe}^{2+} / 10^{6} \mathrm{PMNs} / 20 \mathrm{~min}$. In selected experiments, holosaturated transferrin was initially dialyzed against $0.1 \mathrm{M}$ sodium perchlorate $\left(\mathrm{NaClO}_{4}\right)$ as described previously $(20)$ to remove any contaminating iron and dialyzed against PBS prior to use.

Preparation of transferrin at physiological levels of iron saturalion. Transferrin at physiologic levels of iron saturation (i.e., 30-44\%) was prepared according to previously published methods (21) with minor modifications. Briefly, a $0.2 \mathrm{mM} \mathrm{Fe}^{3+}$ stock solution was prepared by reacting $\mathrm{Fe}^{3+}$ with nitrilotriacetic acid (NTA) at a ratio of 1:4 (21). Sideroferrin $(0.015 \mathrm{mM})$ in $0.01 \mathrm{M}$ Tris buffer $(\mathrm{pH} 7.4)$ was incubated with $\mathrm{Fe} \cdot \mathrm{NTA}(0.010 \mathrm{mM}$ final) in the presence of sodium bicarbonate $\left(\mathrm{NaHCO}_{3} ; 10 \mathrm{mM}\right.$ final) for $30 \mathrm{~min}$ at $22^{\circ} \mathrm{C}$. The percentage iron saturation of the transferrin was determined by comparison of the change in absorbance at $470 \mathrm{~nm}$ of the solution to that of holosaturated transferrin $(0.015 \mathrm{mM})$. The partially iron-saturated transferrin was dialyzed in PBS ( $\mathrm{pH}$ 7.4) containing $\mathrm{NaClO}_{4}$ for $24 \mathrm{~h}$ to chelate any extraneous iron (20). The transferrin solution containing $\mathrm{NaClO}_{4}$ was dialyzed against PBS for $12 \mathrm{~h}$ concentrated in an Amicon concentrator, and dialyzed again in PBS (pH 7.4) containing $1 \mathrm{mM}$ calcium, $0.5 \mathrm{mM}$ magnesium, and $0.1 \%$ dextrose for $12 \mathrm{~h}$. The protein content of the partially iron-saturated transferrin was assessed via the Bradford protein assay with bovine serum albumin (BSA) as a standard (22). Transferrin, at physiologic levels of iron saturation, was then utilized in assays using methodology previously described for holosaturated transferrin.

Release of $\mathrm{Fe}^{3+}$ from transferrin. The release of $\mathrm{Fe}^{3+}$ from transferrin by conditioned media from unstimulated and PMA-stimulated PMNs was determined. PMNs $\left(2.5 \times 10^{6} / \mathrm{ml}\right)$ were incubated with SOD $(90$ $\mathrm{U} / \mathrm{ml}$ final) and catalase $(100 \mathrm{U} / \mathrm{ml}$ final) in the presence and absence of PMA (100 ng/ml final) for $10 \mathrm{~min}$. Following centrifugation $(300 \mathrm{~g}$, $\left.10 \mathrm{~min}, 22^{\circ} \mathrm{C}\right)$, PMN-conditioned media $\left(10^{6}\right.$ cell equivalents) was incubated with transferrin $(0.060 \mathrm{mM}$ final $)$ at specific $\mathrm{pH}$ values in the presence of deferoxamine $\left(10 \mathrm{mM}\right.$ final) in a shaking water bath $\left(37^{\circ} \mathrm{C}\right.$, $20 \mathrm{~min}$ ). The release of ferric iron from transferrin was monitored spectrophotometrically by the decrease in absorbance of transferrin at 295 $\mathrm{nm}$, as previously described (6).

Statistical analysis. All data represent the mean \pm the standard error of the mean (SEM) from at least three experiments. PMNs used in a given experiment were from a single healthy donor. Different donors were used in each experiment. A one factor analysis of variance (ANOVA) and Scheffe $F$ test were performed to compare differences between treatment groups. In appropriate experiments, the Student's paired $t$ test was used to compare differences between treatment groups. ( $P$ $<0.05$ was considered significant).

\section{RESULTS}

The ability of PMNs to secrete $\mathrm{O}_{2}^{-}$at $\mathrm{pH} 7.4$ in response to stimulation with PMA (100 $\mathrm{ng} / \mathrm{ml}$ final) was determined. While unstimulated PMNs secreted negligible amounts of $\mathrm{O}_{2}^{-}(<1 \mathrm{nmol} / \mathrm{min})$, following stimulation with PMA $(100 \mathrm{ng} / \mathrm{ml}$ final $)$, the initial rate of $\mathrm{O}_{2}^{-}$secreted by $10^{6} \mathrm{PMNs}$ was $12.04 \pm 0.77 \mathrm{nmol} \mathrm{O}_{2}^{-} / \mathrm{min}(n=8)$. This is consistent with previously published reports (23). The effect of the presence of transferrin on PMN respiratory burst was also determined. Results of these experiments (data not shown) indicate that inclusion of transferrin in the reaction does not alter the rate of oxygen consumption by unstimulated or PMA-stimulated PMNs.

The ability of unstimulated and PMA-stimulated PMNs to facilitate the release of $\mathrm{Fe}^{2+}$ from holosaturated transferrin at $\mathrm{pH} 7.4$ was assessed (Table I). While unstimulated PMNs facilitated the release of minimal amounts of iron $(0.11 \mathrm{nmol})$ from holosaturated transferrin (98\%), stimulation of PMNs with PMA (100 ng/ $\mathrm{ml}$, final) enhanced the release of $\mathrm{Fe}^{2+}$ from transferrin approximately eightfold. Dialysis of holosaturated transferrin in $0.1 \mathrm{M} \mathrm{NaClO}_{4}$ prior to use did not significantly alter the ability of PMA-stimulated PMNs to facilitate the release of $\mathrm{Fe}^{2+}$ from transferrin (data not shown). Similar results were also obtained in reactions in the absence of catalase (data not shown). Addition of SOD (90 $\mathrm{U} / \mathrm{ml}$ ) to PMA-stimulated PMNs prior to incubation resulted in the release of a small amount of iron $(0.17 \mathrm{nmol})$ from holosaturated transferrin, while incubation of PMAstimulated PMNs with heat-inactivated SOD $\left(80^{\circ} \mathrm{C}, 60\right.$ min) failed to significantly inhibit the release of $\mathrm{Fe}^{2+}$ from transferrin by PMA-stimulated PMNs $(P>0.05)$. These results suggest that the release of $\mathrm{Fe}^{2+}$ from holosaturated 
TABLE I

Effect of Stimulated PMNs on $\mathrm{Fe}^{2+}$ Release

From Transferrin at $\mathrm{pH} 7.4$

\begin{tabular}{lccc}
\hline \multicolumn{1}{c}{ Cells } & $\begin{array}{c}\text { Transferrin } \\
\text { (\% iron saturation) }\end{array}$ & $\begin{array}{c}\text { Nanomoles } \\
\mathrm{Fe}^{2+} \text { released }\end{array}$ & $\begin{array}{c}\% \text { Total } \\
\text { iron released }\end{array}$ \\
\hline PMN & 98 & $0.11 \pm 0.03$ & 0.09 \\
PMN + PMA & 98 & $0.82 \pm 0.09^{*}$ & 0.70 \\
PMN + PMA & & & \\
$\quad$ + SOD & 98 & $0.17 \pm 0.00^{* *}$ & 0.14 \\
PMN + PMA & & & \\
$\quad$ + Heated SOD & 98 & $0.63 \pm 0.09$ & 0.54 \\
PMN & 32 & $0.06 \pm 0.06$ & 0.16 \\
PMN + PMA & 32 & $0.07 \pm 0.07$ & 0.18 \\
\hline
\end{tabular}

Note. Iron-saturated transferrin $[0.060 \mathrm{mM}$ transferrin; $98 \%$ saturated (117.6 $\mu \mathrm{M}$ iron total) $]$ and partially iron-saturated transferrin $[0.060$ $\mathrm{mM}$ transferrin; $32 \%$ saturated (38.4 $\mu \mathrm{M}$ iron total)] were incubated with $10^{6}$ unstimulated and stimulated [PMA (100 ng/ml)] PMNs and nmol of $\mathrm{Fe}^{2+}$ released/20 min were determined. The effect of SOD $(90 \mathrm{U} / \mathrm{ml})$ and heat-inactivated $\operatorname{SOD}\left[80^{\circ} \mathrm{C}, 60 \mathrm{~min}(90 \mathrm{U} / \mathrm{ml})\right]$ on the release of $\mathrm{Fe}^{2+}$ from holosaturated transferrin by stimulated PMNs was also assessed.

* Significantly different from unstimulated PMN.

** Significantly different from PMA-stimulated PMNs (ANOVA; $P$ $<0.05)$.

transferrin by PMNs was dependent on PMN-derived $\mathrm{O}_{2}^{-}$. Furthermore, the ability of PMNs to competitively bind $\mathrm{Fe}^{2+}$, resulting in a potential decrease in the amount of $\mathrm{Fe}^{2+}$ bound to BPS and an underestimation of the amount of $\mathrm{Fe}^{2+}$ released from transferrin by $\mathrm{PMN}$-derived $\mathrm{O}_{2}^{-}$was also determined. PMNs were incubated with BPS and a known concentration of $\mathrm{Fe}^{2+}$. The amount of $\mathrm{Fe}^{2+}$ chelated to BPS in PMN-conditioned media was then compared to that bound to BPS that had been incubated with the same concentration of $\mathrm{Fe}^{2+}$ in the absence of PMNs. Results of these experiments (data not shown) indicate that the same concentration of $\mathrm{Fe}^{2+}$ is bound to BPS in reactions in the presence and absence of PMNs, indicating that PMNs do not bind significant amounts of $\mathrm{Fe}^{2+}$

The ability of PMN-derived extracellular $\mathrm{O}_{2}^{-}$to facilitate the release of $\mathrm{Fe}^{2+}$ from transferrin at physiologic levels of iron saturation (32\%) and $\mathrm{pH} 7.4$ was determined. In contrast to holosaturated transferrin, incubation of unstimulated or PMA-stimulated PMNs with partially iron-saturated transferrin failed to increase the release of $\mathrm{Fe}^{2+}$ at physiologic $\mathrm{pH}$ (Table I).

The effect of decreasing the $\mathrm{pH}$ (by addition of $\mathrm{HCl}$ ) on the release of $\mathrm{Fe}^{2+}$ from transferrin was assessed (Table II). $\mathrm{No} \mathrm{Fe}^{2+}$ is released from transferrin at $\mathrm{pH} 6.6$ or 6.2 in the absence of a reducing agent. While incubation of unstimulated PMNs at either $\mathrm{pH} 6.6$ or 6.2 with holosaturated transferrin $(98 \%)$ resulted in the release of minimal amounts of $\mathrm{Fe}^{2+}(<1 \mathrm{nmol})$, the amount of $\mathrm{Fe}^{2+}$ released from holosaturated transferrin at these mildly acidic pHs was markedly enhanced following incubation with PMA-stimulated PMNs. $\mathrm{Fe}^{2+}$ release was inhibited following incubation of PMNs with SOD. In contrast, addition of heat-inactivated SOD failed to significantly inhibit $\mathrm{Fe}^{2+}$ release from holosaturated transferrin by PMA-stimulated PMNs at $\mathrm{pH} 6.6$ and 6.2 (data not shown). Incubation of PMA-stimulated PMNs at $\mathrm{pH} 6.6$ or 6.2 with transferrin at physiologic levels of iron saturation $(39.63 \% \pm 2.02)$ resulted in the release of 1.15 $\pm 0.27 \mathrm{nmol}$ and $1.82 \pm 0.48 \mathrm{nmol}$ of $\mathrm{Fe}^{2+}$, respectively (Table II). The increased release of $\mathrm{Fe}^{2+}$ from partially

TABLE II

Effect of Decreasing the $\mathrm{pH}$ and Superoxide Dismutase on $\mathrm{Fe}^{2+}$ Release by PMNs

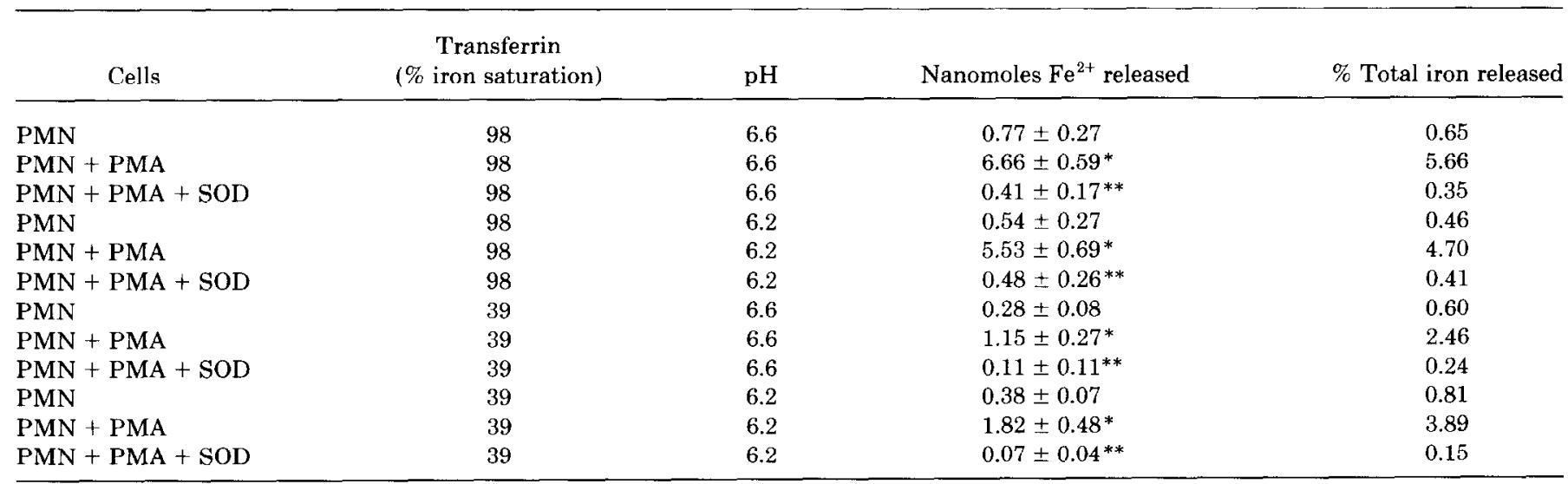

Note. Iron-saturated transferrin $[0.060 \mathrm{mM}, 98 \%$ saturated $(117.6 \mu \mathrm{M}$ iron total $)]$ and partially saturated transferrin [0.060 mM, $39 \%$ saturated $\left(46.80 \mu \mathrm{M}\right.$ iron total)] were incubated with $10^{6}$ unstimulated and stimulated [PMA $\left.(100 \mathrm{ng} / \mathrm{ml})\right] \mathrm{PMNs}$ at $\mathrm{pH} 6.6$ and 6.2 and $\mathrm{nmol}$ of Fe ${ }^{2+}$ released $/ 20$ min were determined. The effect of $\mathrm{SOD}(90 \mathrm{U} / \mathrm{ml})$ on the release of $\mathrm{Fe}^{2+}$ from transferrin by stimulated PMNs was also assessed.

* Significantly different from unstimulated PMNs.

** Significantly different from PMA-stimulated PMNs (ANOVA; $P<0.05$ ). 

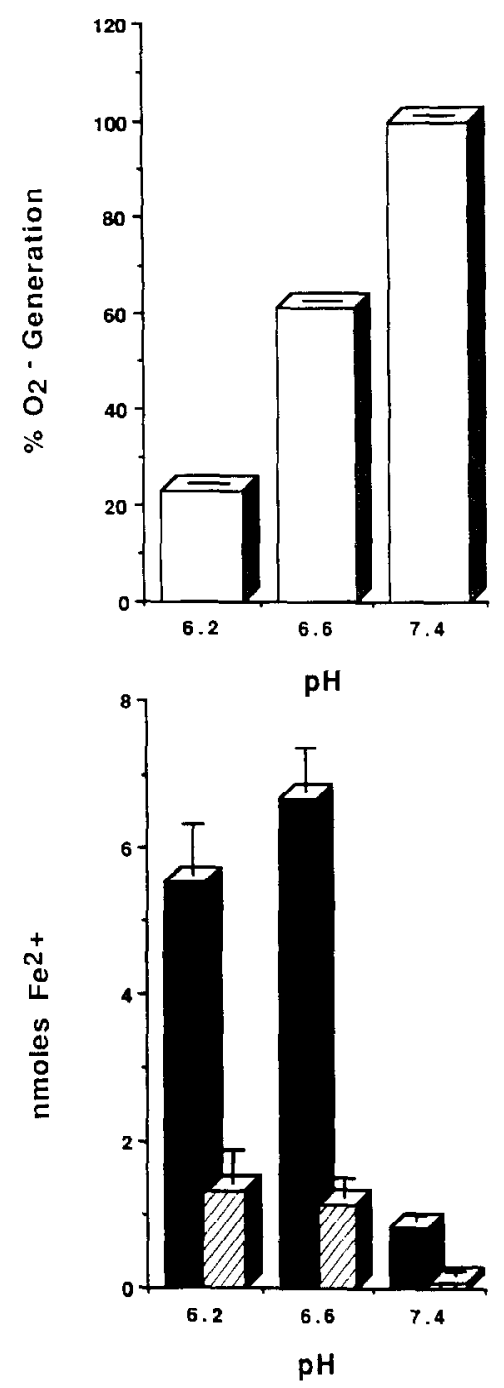

FIG. 1. Effect of decreasing $\mathrm{pH}$ on nanomoles of iron released from transferrin and superoxide anion production by PMA-stimulated PMNs. घ, nmole $\mathrm{Fe}^{21}$ released from holosaturated transferrin $[0.060 \mathrm{mM} ; 98 \%$ iron saturated (117.6 $\mu \mathrm{M}$ iron total)]; $\mathrm{K}, \mathrm{nmol} \mathrm{Fe}^{2+}$ released from partially saturated transferrin $[0.060 \mathrm{mM} ; 32-34 \%$ iron saturated $(38.4-40.8 \mu \mathrm{M})]$, $\square, \% \mathrm{O}_{2}^{-}$generated by $10^{6} \mathrm{PMA}$-stimulated PMNs $(100 \%=167 \mathrm{nmol}$ $\mathrm{O}_{2}^{-} / 10^{6} \mathrm{PMA}$-stimulated PMNs/20 min at $\mathrm{pH}$ 7.4).

saturated transferrin at $\mathrm{pH} 6.6$ and 6.2 was also inhibited by SOD (Table II) and occurred despite a pH-dependent decrease in extracellular $\mathrm{O}_{2}^{-}$generation (Fig. 1).

In further experiments, a more detailed study on the effect of decreasing $\mathrm{pH}$ on the release of ferrous iron from transferrin at physiologic levels of iron saturation was performed. For these studies, PMA-stimulated neutrophils were incubated with transferrin at physiologic levels of iron saturation ( $39 \%$ saturated) at $0.2 \mathrm{pH}$ increments between $\mathrm{pH} 6.6$ and 7.4. At $\mathrm{pH} \mathrm{6.8,0.59} \mathrm{nmol}$ of $\mathrm{Fe}^{2+}$ was released by PMA-stimulated neutrophils compared to 0.28 $\mathrm{nmol}$ of $\mathrm{Fe}^{2+}$ released from transferrin in the presence of unstimulated neutrophils. At pH 7.0, 7.2, and 7.4 PMAstimulated PMNs did not facilitate the release of en- hanced amounts of $\mathrm{Fe}^{21}$ from transferrin. Results of these experiments indicate that neutrophil-derived superoxide ion facilitates the release of enhanced amounts of ferrous iron from transferrin at $\mathrm{pHs}$ equal to and less than $\mathrm{pH} 6.8$.

To determine if $\mathrm{PMN}$-derived $\mathrm{O}_{2}^{-}$facilitated the release of $\mathrm{Fe}^{3+}$ from transferrin, unstimulated and PMA-stimulated PMNs were incubated with holosaturated transferrin and deferoxamine (a $\mathrm{Fe}^{3+}$ chelator) in the presence and absence of SOD. The release of $\mathrm{Fe}^{3+}$ from holosaturated transferrin was assessed spectrophotometrically by the formation of a $\mathrm{Fe}^{3+}$-deferoxamine complex in PMNconditioned media. Results of these experiments (data not shown) indicate that equivalent amounts of $\mathrm{Fe}^{3+}$ are released from transferrin by unstimulated and PMAstimulated PMNs. To further address the ability of secretory products derived from PMA-stimulated PMNs to enhance $\mathrm{Fe}^{3+}$ release from transferrin, conditioned media from unstimulated and PMA-stimulated PMNs was incubated with iron-saturated transferrin $(98 \%)$ and partially saturated transferrin $(34 \% \pm 1.73)$ in the presence of deferoxamine (Table III). As indicated by the decrease in absorbance of transferrin at $295 \mathrm{~nm}$, conditioned media from unstimulated or PMA-stimulated PMNs was equally effective in facilitating the release of $\mathrm{Fe}^{3+}$ from transferrin, suggesting that secretory products of stimulated PMNs do not effect the release of $\mathrm{Fe}^{2+}$ from transferrin at mildly acidic $\mathrm{pH}$ by enhancing $\mathrm{Fe}^{3+}$ labilization. Furthermore, this data suggests that approximately four times more labile $\mathrm{Fe}^{3+}$ is available from holosaturated transferrin than from partially saturated transferrin at $\mathrm{pH}$ 7.4. As the $\mathrm{pH}$

\section{TABLE III}

Effect of PMN Supernatants on $\mathrm{Fe}^{3+}$ Release from Transferrin

\begin{tabular}{lccl}
\hline $\begin{array}{c}\text { PMN-Conditioned } \\
\text { media }\end{array}$ & \% Saturation & $\mathrm{pH}$ & $\begin{array}{c}\text { Decrease in } \\
\text { absorbance } 295 \mathrm{~nm}\end{array}$ \\
\hline Unstimulated & 98 & 7.4 & $0.095 \pm 0.048$ \\
PMA Stimulated & 98 & 7.4 & $0.122 \pm 0.027 \mathrm{NS}$ \\
Unstimulated & 98 & 6.6 & $0.631 \pm 0.065$ \\
PMA Stimulated & 98 & 6.6 & $0.549 \pm 0.048 \mathrm{NS}$ \\
Unstimulated & 98 & 6.2 & $0.836 \pm 0.049$ \\
PMA Stimulated & 98 & 6.2 & $0.800 \pm 0.044 \mathrm{NS}$ \\
Unstimulated & 34 & 7.4 & $0.025 \pm 0.025$ \\
PMA Stimulated & 34 & 7.4 & $0.033 \pm 0.009 \mathrm{NS}$ \\
Unstimulated & 34 & 6.6 & $0.182 \pm 0.018$ \\
PMA Stimulated & 34 & 6.6 & $0.158 \pm 0.024 \mathrm{NS}$ \\
Unstimulated & 34 & 6.2 & $0.182 \pm 0.015$ \\
PMA Stimulated & 34 & 6.2 & $0.152 \pm 0.043 \mathrm{NS}$ \\
\hline
\end{tabular}

Note. Iron-saturated transferrin $[0.060 \mathrm{mM}, 98 \%$ saturated $(117.6 \mu \mathrm{M}$ iron total) $]$ and partially saturated transferrin $[0.060 \mathrm{mM}, 34 \%$ saturated (40.8 $\mu \mathrm{M}$ iron total)] were incubated with conditioned media from unstimulated and stimulated [PMA $(100 \mathrm{ng} / \mathrm{ml})]$ PMNs $\left(10^{6}\right.$ equivalents $)$ in the presence of deferoxamine ( $10 \mathrm{mM}$ final) and the decrease in $a b$ sorbance $(295 \mathrm{~nm})$ of transferrin $/ 20 \mathrm{~min}$ was assessed. $\mathrm{NS}=$ no significant difference between unstimulated and stimulated PMN-conditioned media. 
is decreased, significantly more $\mathrm{Fe}^{3 \dagger}$ is labilized from transferrin due to $\mathrm{pH}$-dependent conformational changes in the transferrin - iron - bicarbonate complex (6).

\section{DISCUSSION}

PMN-derived $\mathrm{O}_{2}^{-}$facilitated the release of $\mathrm{Fe}^{2+}$ from iron-saturated transferrin at physiologic $\mathrm{pH}$, yet failed to facilitate the release of $\mathrm{Fe}^{2+}$ from transferrin at physiologic levels of iron saturation at $\mathrm{pH}$ 7.4. This is in agreement with a previous report by Biemond et al. (16) which suggests that at physiologic $\mathrm{pH}$, stimulated PMNs failed to mobilize iron from partially saturated $(60 \%)$ transferrin. Furthermore, previous studies at physiologic $\mathrm{pH}$ by Aruoma et al. (24) provide indirect evidence that is consistent with the hypothesis that $\mathrm{O}_{2}^{-}$, in the presence of EDTA, only minimally mobilizes iron from saturated transferrin. Other studies have shown that $\mathrm{O}_{2}^{-}$does not directly react with $50 \%$ iron-saturated transferrin (25). As a result of these findings, the role of transferrin as a source of iron for biological reactions at sites of acute inflammation has been questioned $(16,26)$.

As an extension of these studies, we determined the effect of decreasing the $\mathrm{pH}$ on the ability of PMN-derived $\mathrm{O}_{2}^{-}$to facilitate the release of $\mathrm{Fe}^{2+}$ from holosaturated transferrin and from transferrin at physiologic levels of iron saturation. It has been demonstrated that iron release from transferrin can be modulated by several factors including $\mathrm{pH}(2,3,6,27)$. As the $\mathrm{pH}$ is decreased, the stability of the $\mathrm{Fe}^{3+}$ transferrin - bicarbonate complex decreases, rendering the metal susceptible to reduction (3). We found that decreasing the $\mathrm{pH}$ to 6.6 and 6.2 facilitated the release of $\mathrm{Fe}^{2+}$ from holosaturated transferrin by unstimulated and PMA-stimulated PMNs. The enhanced release of $\mathrm{Fe}^{2+}$ under mildly acidic conditions occurred despite a decrease in the amount of $\mathrm{O}_{2}^{-}$generated by PMAstimulated cells, indicating an increased efficiency in $\mathrm{O}_{2}^{-}$-dependent reduction of $\mathrm{Fe}^{3+}$. Our results are consistent with those of Saito et al. (26) who concluded that the amount of $\mathrm{Fe}^{2+}$ released from holosaturated transferrin by xanthine-xanthine oxidase-derived $\mathrm{O}_{2}^{-}$was greatly enhanced by decreasing the $\mathrm{pH}$.

Of potentially greater biological significance, results of our studies indicate that decreasing the $\mathrm{pH}$ facilitated the release of $\mathrm{Fe}^{2+}$ from partially saturated transferrin by PMN-derived $\mathrm{O}_{2}^{-}$, achieving concentrations in our assay system of greater than $1 \mu \mathrm{M}$. Since the plasma concentration of transferrin is approximately $25-35 \mu \mathrm{M}(28)$, these data suggest that similar concentrations of $\mathrm{Fe}^{2+}$ may be released from transferrin at sites of acute inflammation due to $\mathrm{PMN}$-derived $\mathrm{O}_{2}^{-}$-dependent reduction of labilized $\mathrm{Fe}^{3+}$. Furthermore, comparable amounts of $\mathrm{Fe}^{2+}$ were released from partially saturated transferrin by PMA-stimulated $\mathrm{PMNs}$ at $\mathrm{pH} 6.6$ and 6.2, despite a progressive decrease in the amount of $\mathrm{O}_{2}^{-}$generated by PMA-stimulated PMNs as the acidity increased. This indicates an increased efficiency of $\mathrm{Fe}^{2+}$ release from partially saturated transferrin by $\mathrm{PMN}$-derived $\mathrm{O}_{2}^{-}$in mildly acidic conditions similar to that observed with holosaturated transferrin. Thus, we suggest that, at sites of tissue injury, the release of $\mathrm{Fe}^{2+}$ from transferrin at physiologic levels of iron saturation by $\mathrm{PMN}$-derived $\mathrm{O}_{2}^{-}$is dependent on the hydrogen ion-mediated destabilization of the $\mathrm{Fe}^{3+} \cdot$ transferrin $\cdot$ bicarbonate complex making the $\mathrm{Fe}^{3+}$ more susceptible to reduction.

$$
\begin{gathered}
\text { Inflammation/ischemia } \\
\mathrm{H}^{+} \quad \mathrm{PMN-derived} \mathrm{O}_{2}^{-} \\
\mathrm{Fe}^{3+} \cdot \mathrm{TRF} \cdot \mathrm{CO}_{3}^{2-} \downarrow\left[\mathrm{Fe}^{3+} \cdot \mathrm{TRF} \cdot \mathrm{CO}_{3}^{2-}{ }^{\downarrow} \mathrm{APOTRFCO}_{3}^{2-}+\mathrm{Fe}^{2+},\right.
\end{gathered}
$$

where TRF and APOTRF are transferrin and apotransferrin, respectively, and $\left[\mathrm{Fe}^{3+} \cdot \mathrm{TRF} \cdot \mathrm{CO}_{3}^{2-}\right]$ indicates the destabilized conformational state of transferrin.

In conclusion, transferrin at physiologic levels of iron saturation can serve as a source of $\mathrm{Fe}^{2+}$ for participation in biological reactions including propagation of lipid peroxidation and generation of hydroxyl radical formation following reaction with phagocytic cell-derived hydrogen peroxide. The restriction of this effect to conditions of mildly acidic $\mathrm{pH}$ and the presence of a reducing agent like $\mathrm{PMN}$-derived $\mathrm{O}_{2}^{-}$limits its pathophysiologic role to disease processes that result in a significant decrease in tissue $\mathrm{pH}$ [e.g., sites of inflammation (29), ischemic injury (30)] or within the microenvironment of activated phagocytic cells where the $\mathrm{pH}$ at the cell surface is less than $6.0(31)$.

\section{ACKNOWLEDGMENTS}

This research was supported in part by National Institutes of Health Grants RR-07008, RR-00200, HL-32024, HL-28737, DK-39255, HL44085 and RR-00040.

\section{REFERENCES}

1. Aust, S., Morehouse, L., and Thomas, C. (1985) J. Free Rad. Biol. Med. 1, 325.

2. Carver, F., and Frieden, E. (1978) Biochemistry 17, 167-172.

3. Kojima, N., and Bates, G. (1979) J. Biol. Chem. 254, 8847-8854.

4. Harris, D., Rinehart, A., Hereld, D., Schwartz, R., Burke, F., and Salvador, A. (1985) Biochim. Biophys. Acta. 838, 295-301.

5. Hubers, H., and Finch, C. (1987) Physiol. Rev. 67, 520-528.

6. Morgan, E. (1979) Biochim. Biophys. Acta 580, 312-326.

7. Braughler, J., Duncan, L., and Chase, R. (1986) J. Biol. Chem. 261, $10,282-10,289$.

8. Gaber, B., and Aisen, P. (1970) Biochim. Biophys. Acta 221, 228233.

9. Aisen, P., Leibman, A., and Zweier, I. (1978) I. Biol. Chem. 253, 1930-1937.

10. Morgan, E., Huebers, H., and Finch, C. (1978) Blood 52, 1219 1228.

11. Lestas, A. (1976) Brit. J. Haematol. 32, 341-350.

12. Ketchmar, S., and Raymond, K. (1986) J. Amer. Chem. Soc. 108, 6212-6218.

13. Konopka, K., Bindereif, A., and Nieland, .I. (1982) Biochemistry 21, 6503-6508. 
14. Bates, G. (1981) Fifth International Conference on Protein, Iron Storage, and Transport, San Diego and La Jolla, CA.

15. Fantone, J., and Ward, P. (1982) Amer. J. Pathol. 107, 397-418.

16. Biemond, P., van Eijk, H., Swaak, A., and Koster, J, (1984) J. Clin. Invest. 73, 1576-1579.

17. Salin, M., and McCord, J. (1974) J. Clin. Invest. 54, 1005-1009.

18. Boyum, A. (1967) Scand. J. Clin. Lab. Invest. 21(Suppl. 97), 7789.

19. Babior, B., Kipnes, R., Curnutte, J. (1972) J. Clin. Invest. 52, 741744.

20. Baldwin, D., .Jenny, E., and Aisen, P. (1984) J. Biol. Chem. 259, $13,391-13,394$.

21. Graham, G., and Bates, G. (1976) J. Lab. Clin. Med. 88, 477-486.

22. Bradford, M. (1976) Anal. Biochem. 72, 248-254.
23. Guthrie, L. A., McPhail, L. C., Henson, P. M., and Johnston, R. B (1984) J. Exp. Med. 160, 1656-1671.

24. Arumoa, O. I., and Halliwell, B. (1987) Biochem. J. 241, 273-278.

25. Buettner, G. R. (1987) J. Biol. Chem. 262, 11,995-11,998.

26. Saito, M., Morehouse, L., and Aust, S. (1986) J. Free Rad. Biol. Med. 2, 99-105.

27. Pollack, Vanderhoft, and Lasky, F. (1977) Biochim. Biophsy. Acta. 497, 481-487.

28. Bostian, K. A., Blackburn, B. S., Wannemacher, R. W., McGann, V. G., and Biesel, W. R. (1976) J. Lab. Clin. Med. 87, 577-585.

29. Edlow, D. W., and Sheldon, W. H. (1971) Proc. Soc. Exp. Med. 137, 1378-1382.

30. Chance, B., Clark, B. J., Nioka, S., Subramanian, H., Maris, J. M., Argo, V. Z, and Bode, H. (1985) Circulation 72(SIV), 103-110.

31. Etherington, D., Pugh, D., and Silver, I. (1981) Acta Biol. Med. Germ. 40, 1625-1636. 